\title{
Complete Khoya Replacement in Mango Burfi to Increase Shelf Life: A Case Study
}

\author{
Smita Lele*, Tripti Pandey and Shanooba PM \\ Department of Food Engineering and Technology, India \\ *Corresponding author: Smita Lele, Department of Food Engineering and Technology, India \\ Submission: 眥 September 25, 2017; Published: 眥 November 14, 2017
}

\section{Introduction}

Khoya is a heat coagulated partially dehydrated whole milk product obtained by heating, evaporation \& desiccation at atmospheric pressure. The main reaction in the preparation of khoya is the heat denaturation and coagulation of milk proteins. Most of the albumins \& globulins are rapidly denatured, the protective properties of the other colloids are destroyed during boiling and the process is accelerated by incorporation of air seen as frothing by constant stirring or container rotation. Albumin and globulins are coagulated below $100{ }^{\circ} \mathrm{C}$, while casein is coagulated above $100{ }^{\circ} \mathrm{C}$. The factors that influence the heat coagulation are temperature and hold up time, concentration of casein, acidity of milk and salt balance [1].

Shelf life of khoya at refrigerated temperature is three weeks and two to four days at ambient temperature [2,3]. Kumar et al. [4] studied the packaging of khoya in laminates of paper/Aluminium foil/Low Density Polyethylene (LDPE) and 4-ply laminated pouches made of Polypropylene/LDPE/Aluminium foil/LDPE and showed a shelf-life of 60 days and 75 days respectively. Handling and storage conditions are equally important as initial quality of milk to maintain quality of khoya. Presently almost a million tonnes of Khoya valued at INR 45,000 million is produced in the country annually. Small scale food processing units, commonly known as sweetmeat shops are in very large numbers in India with an annual sales turnover of INR 150 billion. The handling of khoya at small scale is not so hygienic due to which the khoya can very easily get contaminated, also storage at clean, dirt free, dark place at constant temperature is quite difficult at such sweetmeat shops or small scale industries. At high preparation temperature of khoya, all the existing microorganisms get killed but the spores will survive whereupon such mishandling, temperature fluctuation and improper packaging \& storage conditions, keeping khoya at refrigerated temperatures would not help to preserve its quality. Due to low temperature, might other parameters like biochemical changes get slow but the existence of unharmed spores and contaminating microorganisms of psychrophilic nature proliferates. This flora may or may not be pathogenic, produce toxins or harm full to human after consumption but for sure digest nutrients of khoya by the action of their enzymes like lipase, protease, and lactase etc.
In this study an attempt has been made to replace khoya in suitable dairy confectionary. Mango burfi was chosen as it contains Alphan so mango pulp which has a unique flavour, bright orange colour and this Burfi is very popular in Maharashtra. Typically mango pulp to khoya ratio ranges from 1:1 to 1:3 depending on recipe. While replacing khoya the main challenge was to use replacer constituents which can give the body and desired firm texture without changing the taste and flavour. While keeping an eye on current trends of industry, vegetable proteins are in fashion because of their good nutrition profile. In this work we have used combination of different lentils, vegetable oils and Skim Milk Powder (SMP) to mimic khoya.

\section{Microbial Quality Assessment of Commercial Khoya}

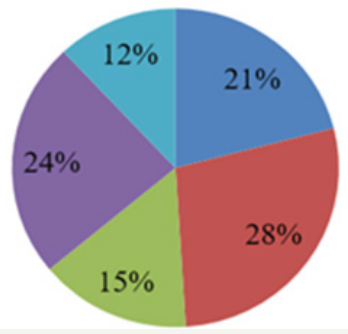

\section{- Bacillus \\ a Pseudomonas \\ = Alcaligens \\ E.Coli \\ Areomonas}

Figure 1: Microbial isolates detected in Khoya procured from Dadar Mumbai.

Food products are source of nutrition and substrates for the growth of microorganisms. Excess of microorganisms in foodstuff causes its spoilage, which if consumed, in turn causes food borne illness. Moreover in tropical countries raw milk and its various products are responsible for many outbreaks of gastrointestinal tract. Singh et al. [5] reported out of 64 Khoya sweets samples, 47 isolates were confirmed as coagulase positive S.aureus and from these 13 were confirmed as pathogenic S.aureus. Reddy et al. [6] reported total plate count of $5 \times 103 \mathrm{CFU} / \mathrm{g}$ to $2.1 \times 105 \mathrm{CFU} / \mathrm{g}$ in Khoya from Hissar market. These reports clearly indicate that although khoya is sterile at the point of production, gets highly contaminated due to bad handling practices and lack of 
awareness at the worker level. We collected 10 samples of Khoya from different shops in market region of Dadar, Mumbai and the microbial quality was assessed. The following genus Bacillus, Pseudomonas, Staphylococcus, E.Coli, and Areomona were detected with percentage distribution as shown in Figure 1.

\section{Study of commercial mango burfi}

Pune based popular sweet meat manufacturer has made a global brand for snack product, however, their mango burfi, an equally popular product has not seen other markets except the home town Pune due to inadequate shelf life. Hence, Mango Burfi produced by two famous brands from Pune, Maharashtra were chosen as standards and were analysed for composition, sensory and texture, colour, microbial quality etc. These controls were used as a standard to compare khoya replaced product developed in this work.

\section{Product formulation}

Mango burfi was made with 50g khoya and Pulverized sugar was added by weight $30 \%$ of khoya. Different trials were run to check the optimum sweetness and distinct prominent mango flavour by sensory analysis on $50 \mathrm{~g}$ of khoya. Finally overall acceptability was considered and 25g of Pulverized Sugar and 50g of Mango pulp $\left(27^{\circ}\right.$ Brix) scored highest of $7.9 \pm 0.19$ and $8.4 \pm 0.42$ respectively. Special product, "khoya replaced mango burfi was made with pea flour, SMP, ghee, starches, mango pulp and sugar. The final product formulation is given in Table 1.

Table 1: Best "Khoya Replaced Mango Burf" Formulation.

\begin{tabular}{|c|c|}
\hline Ingredients & Weight (g) \\
\hline SMP & 25 \\
\hline MP & 50 \\
\hline Sugar & 25 \\
\hline Pea flour & 17 \\
\hline Potato starch & 4 \\
\hline Corn starch & 4 \\
\hline Ghee & 15 \\
\hline Total & $\begin{array}{l}\text { 140(evaporated to get desired } \\
\text { texture and moisture content) }\end{array}$ \\
\hline
\end{tabular}

Further, the biochemical attributes of the product as well as commercial mango burfi samples were compared and the results are given in Table 2 .

Table 2: Biochemical attributes of commercial brands and 100\% khoya replaced mango burfi.

\begin{tabular}{|c|c|c|c|}
\hline Component \% & Mangoburfi (Brand 1) & Mangoburfi (Brand 2) & 100\% Khoya Replaced Mangoburfi \\
\hline Moisture & $9.8+0.05$ & $16.9+0.08$ & $11.0+0.04$ \\
\hline Fat & $2.0+0.02$ & $9.0+0.01$ & $13.0+0.03$ \\
\hline Protein & $1.26+0.01$ & $2.3+0.16$ & $37.0+0.007$ \\
\hline Carbohydrate & $61.94+0.06$ & $40.3+0.36$ & $21.0+0.012$ \\
\hline Fiber & $23.0+0.10$ & $27.0+0.02$ & $3.0+0.03$ \\
\hline Ash & $2.0+0.09$ & $4.5+0.08$ & 2 \\
\hline
\end{tabular}

\section{Shelf life studies}

Sample with highest overall acceptability score was selected and studied for shelf-life under two different temperature conditions i.e. $4{ }^{\circ} \mathrm{C}$ and $30{ }^{\circ} \mathrm{C}$ under vacuum in multilayers packaging films $\mathrm{B} 3 \mathrm{Al}$ layers. Under shelf-life study the samples at $4{ }^{\circ} \mathrm{C}$ gave showed with minimum changes for 70 days. At higher temperature the packaged product had a shelf-life of 35 days.

\section{Conclusion}

The high nutritional value of khoya is a good for health but other perimeters like high water activity(aw), non-acidic nature etc. advocates the replacement of khoya in these kind of products with potential substitute. Replacement of khoya not only provides shelflife to product but also strengthen the potential of these sweetmeats to get exported. Many ingredients especially hydrocolloids can be considered for this purpose as they are flavour less and can give clean labels.
With the bases that khoya is a coagulated milk protein surrounded and embedding fat, lactose and other components of milk, one can try to restructure khoya with many ingredients like different proteins to give texture and network, other sugars for sweetness, ghee or oil as a source of fat and lastly whey proteins or powder to give the milky flavour to give a real feel of an milk product. Many combinations with hydrocolloids, hydrocolloidsproteins, polysaccharide-proteins can be studied.

\section{References}

1. Gupta SK, Patil GR, Patel AA, Garg FC, Rajorhia GS (1990) Instron texture profile parameters of khoya as influenced by composition. Journal of Food Science and Technology 27(4): 209-213.

2. Palit C, Pal D (2005) Studies on mechanized production and shelf life extension of burfi. Indian Journal of Dairy Science 58(1): 12-16.

3. Salariya AM, Rehman Z (2006) Effect of synthetic antioxidants on storage stability of khoya-a semi-solid concentrated milk product, Food Chem 96(1): 122-125. 
4. Kumar A, Rajorhia GS, Srinivasan MR (1975) Effect of modern packaging materials on keeping quality of khoya. Journal of Food Science and Technology 12: 172-177.

5. Singh P, Prakash A (2010) Prevalence of coagulase positive pathogenic Staphylococcus aureus in milk and milk products collected from unorganized sector of Agra. Acta argiculturae Slovenica 96(1): 37-41.
6. Reddy GR, Reddy KS, Mandokhot UV, Chandiramani NK (1983) Survey and growth of microflora in Khoya at different storage conditions. In: Microorganisms in Agriculture and Ecology, Proceedings of the symposia on biology of virus plasmids and biotechnology, $24^{\text {th }}$ Annual conference of Association of Microbiologist of India, Hyderabad, India. 